Indian science congress

\title{
Pursuit of quality endorsed
}

\section{Mesra, Bihar}

STRINGENT control of higher degrees and special schools for highly gifted children were among the recommendations of the 71st Indian National Science Congress, which met at the Birla Institute of Technology in Mesra last week.

The congress, which resembles a cross between the British Association and a political rally has, since 1976, had a "keynote theme", on which it presents recommendations to the relevant government bodies, and on which it receives an implementation report in the following session. This year's theme was "Quality science in India - ends and means".

This slogan was interpreted in different ways, Professor M.G.K. Menon made an impassioned plea on the serendipity value of basic research. The Prime Minister, Mrs Indira Gandhi, who opened the congress, argued that, since "quality of science" presupposed "quality of life", it implied a joint campaign of scientists against the threat of nuclear war and the subsequent ecological disaster. By the second day, however, the keynote theme had crystallized into how to overcome the prevailing mediocrity of Indian science.

India, as a number of speakers noted, can claim the world's third largest "scientific work-force" in the sense of employed persons with at least a first degree in science. In establishing this human resource, which is vital for the development of Indian agriculture and industry, there has been a concentration on quantity rather than quality of graduates. Furthermore, the low remuneration of young research fellows (around 600 rupees - $£ 40$ - a month, or about half the salary of a young graduate entering business or the civil service) means an inevitable wastage on financial grounds. The congress president, Professor R.P. Bambah of Punjab University, maintained that unless research fellows immediately have their stipends doubled, there is no long-term hope for Indian science.

This utopian suggestion did not find its way into the draft "recommendations" which this year seem aimed as much at the scientific community itself as at the government. On the subject of pay, the "recommendations" firmly reject the new scheme of promotion of lecturers to readers and readers to professors on the basis of length of service. This scheme has recently been introduced, under trade union pressure, at a few leading universities, including Delhi, in place of the existing system of promotion by merit as and when a vacancy occurs. The new system, many argued, is a blueprint for apathy and complacency.

One practical suggestion for improving scientific "quality" was that the titles and abstracts of PhD theses should be published together with the names of the adjudicators awarding the degree. This is intended to counteract the frequently reported slackness and even downright dishonesty in the degree process. At the same time, criteria for higher degrees should be standardized because several universities have acquired a reputation for "easy" PhDs. Government agencies which award research fellowships should establish a joint selection examination, and awards should be made on the basis of merit only - ending the present "positive discrimination" in favour of the disadvantaged. The civil service requirement that certain posts must be filled by graduates should be revoked, thereby reducing the pressure on the universities.

In general, Indian education was felt to be too examination-oriented - and Professor Bambah's suggestion of "pacesetting" schools for the highly gifted was based on the concept that such young people could better develop their potential in a peer group in which they would learn to work together as a team.

The congress itself had a competitive aspect - competitive awards to young postgraduate scientists selected by the Indian National Academy of Sciences and by the congress. Ironically, the first award announced was for work on RNA. Yet, although it recently hosted a major genetics conference and in spite of the importance of the subject for agriculture, India has been able to establish virtually no university departments of genetics apparently because of a preponderance of classical botanists and zoologists in the upper echelons of the life sciences.

Vera Rich

\section{Educational computing}

\section{Academics gain from competition}

Pasadena, California

COMPETITION in the computer industry is nothing new, but computer companies are now competing for an unusual prize - the privilege of giving away millions of dollars of equipment to universities. In recent months the California Institute of Technology (Caltech) has received computers worth some $\$ 1.4$ million from HewlettPackard and Data General at a 75 per cent discount, Massachusetts Institute of Technology (MIT) has closed a deal with IBM and Digital Equipment Corporation (DEC) under which those companies will donate $\$ 50$ million in equipment and support over five years and IBM has announced a programme of grants to 20 universities totalling \$50 million in hardware for the support of manufacturing engineering education. Many other companies are also offering large numbers of small computers to universities at much reduced cost.

The companies' motives are varied. Those offering bulk deals on work-stations may well be hoping to lock in a future market in personal and business computers. The Caltech and MIT deals, however, appear to reflect the companies' need to tap a body of expertise that they themselves lack, particularly in developing educational software and in assembling large integrated computer networks. Charitable donations to universities also yield $\operatorname{tax}$ benefits to the companies that substantially reduce their net cost. Educational software will probably be the most tangible benefit to the companies. MIT has agreed to offer IBM and DEC non-exclusive licences for any software developed with their equipment.

The present dearth of serious educational software is universally bemoaned. "The state of the art in educational uses of computers is a disaster", says Steven Lerman, an MIT engineering professor who directs the programme there. Most educational software is little more than electronic workbooks, which is "the biggest waste of hardware, software, and people's time ever invented". Lerman foresees the use of computers in a variety of truly novel ways that will take advantage of their unique capabilities. "Dry laboratory" experiments could demonstrate chemical titration, thermodynamic principles and the like with the help of sophisticated graphics - and without wasting valuable laboratory time and space.

MIT is itself raising $\$ 20$ million for the programme. IBM and DEC, besides donating the machines, are providing software and maintenance support and are lending MIT several full-time personnel.

Here at Caltech, the emphasis is also on educational software development. The university is placing three of the four VAXclass Data General machines it has acquired in the hands of undergraduate students. Eventually, these machines are expected to become the central computers in a network that will include multiple work-stations. Geoffrey Fox, a theoretical physicist who was recently named Caltech's first dean for educational computing, believes it is a mistake, however, to have one computer to each student. Fox says that to get students to use computers and to stimulate the much needed software development requires a diversity of machines with capabilities beyond the "lowest common denominator" that inevitably determines the selection of a personal computer that will be issued to every student. Fox points to one US university that acquired an IBM personal computer for every freshman, only to find that the average computer was used for one hour per day for games and for one hour as a terminal for the university's main computer. 